\title{
SOCIAL IDENTIFICATION OF A PERSON THROUGH THE PRISM OF GASTRONOMIC CULTURE OF UKRAINIAN SOCIETY
}

\author{
Oksana Makukh', Anastasia Lutsik ${ }^{2}$ \\ Lviv Polytechnic National University, Lviv, Ukraine \\ ${ }^{1}$ associate Professor, Department of Sociology and Social Work \\ ${ }^{2}$ undergraduate of the Department of Sociology and Social Work
}

Introduction. Gastronomic culture in contemporary life has become a clear identifier and litmus of social identification. Gastronomy itself is considered as a communicative background for the formation of social relations, since an urge for collective consumption of food (family feasts, holidays in nature, celebration of events, etc.) may be found in behavior of the Ukrainians. In turn, it is the dissemination of information, discussion of news, and influence on public opinion. These processes have given impetus to the institutionalization of the various daily practices associated with dining.

Nowadays, gastronomy acts as a cognitive concept allowing observing of the formation and development of the differentiation of society, in particular its diagnosis. Within the framework of sociological studies of local scientific discourse, the phenomenon of gastronomic culture has not been sufficiently studies: rather it is fragmentary and theoretical.

Objective. Studying of the impact of the Ukrainians' gastronomic preferences on social identification.

Methods. On the basis of a systematic approach and multidisciplinary vision, the following methods were used: general theoretical methods (analysis, synthesis, generalization based on scientific sources and sociological information); empirical methods (content analysis to determine the actualization of the outlined problem in the domestic scientific discourse), observation (as a postulate of sociological research by C. Mills); behaviorism (since human behavior is a response to the stimuli of the social environment).

Results. Gastronomic culture determines the social identification of the Ukrainians. Studies on this issue have been exacerbated by a gender factor, as gastronomic culture has become one of the indicators of processes of female emancipation, strengthening of the principles of gender egalitarianism: first of all, in the form of stereotyping of mass consciousness, possible dysfunctions in family and marriage relationships. (Nikolenko, 2014).

When choosing meals (including ready-to-eat food), the consumers rely on their own financial resources, often spending more on food than planned. High-level representatives are focused on the quality and assortment of gastronomy, as well as facilities of place to go (interior, show programs, club card, etc.). There is also a percentage of people eating at restaurants or ordering ready-to-eat meals: $7.8 \%$ (State statistics service of Ukraine, 2018). Young people spend their time (previously used on cooking) at public places as a way of identifying themselves with a modern lifestyle and belonging to their group.

Thus, eating has lost its prior function of meeting basic need nowadays, and it is transformed into social situations. Behavioral patterns at the table represent socially entrenched behaviors that are clearly correlated with a particular social stratum of society and structure as a whole.

Conclusion. Nowadays, studies of gastronomic practices through the lens of social identification are being formed in the direction of research, e. g. "food studies". Gastronomy is a significant factor in the processes of formation of social identification (within particular family, social group, and the state as a whole). Local gastronomic studies have a strong praxeological potential in the processes of institutionalization of civic identity and improving the quality of life of a mass individual (Nikolenko, 2015).

Nowadays, Ukrainian gastronomy has not lost its cultural identity and appeal, but the sounded algorithms and metamorphoses face the threat of loss of the individuals' individualization and identification, transforming them into a complete mass.

Keywords: gastronomic culture, gastronomic preferences, social identification, social stratification. 
Виклад основного матеріалу. Перші намагання аналізу гастрономічної культури знаходимо у представників школи «Анналів», котрі відобразили повсякдення споживання їжі у кореляції із соціокультурною системою. Так Ф. Бродель досліджував культуру харчування через призму місця i часу з урахуванням факторів соціального змісту: економічних, політичних, культурних. Вивчення харчування, як соціокультурного феномена, припадає на 1960-70-ті pp. XX ст. і пов’язане з дослідницькими практиками структуралістів. Відтак саме у працях К. Леві-Стросса, М. Дугласа, Р. Барта ідея їжі трактується як «як специфічний культурний код». Варто згадати і про Г. Зіммеля 3 його «Соціологією трапези» (досліджує феномен їжі і трапези в контексті «своєї» методології - формальної соціології), також роботу П. Сорокіна «Голод як фактор. Вплив голоду на поведінку людей, соціальну організацію та суспільне життя» ((Nikolenko, 2015).

Серед вітчизняних дослідників відзначимо роботи В. Бурлачука («Трапеза як предмет соціологічного дослідження»), В. Ніколенка («Гастрономічні детермінанти суспільного життя: соціологічний вимір»), В. Панченко («Українське національне харчування: минуле i майбутнє. Уроки здоров’я») (Nikolenko, 2015; Panchenko, 210; Burlahcuk, 2010).

На даному етапі, відповідно до систематичних даних Державної служби статистики, українці витрачають значну частину свого бюджету на харчування. У 2018 р. витрати на продукти харчування та безалкогольні напої становили $44,5 \%$ доходів. найбільшу частку $(23 \%)$ у структурі «продовольчих» витрат української родини займають м'ясо i м'ясопродукти. 15,8\% витрат припадає на хліб і хлібобулочні вироби, 12,8\% - на молоко, сир і яйця. Відносно незначні витрати українців на овочі (включаючи картоплю), і фрукти разом приблизно 14\% (менше 500 гривень) (Derzavna sluzhba statystyky Ukrayiny, 2018).

У 2017 р. - це вже 47,9\%. Тобто майже половина витрат української сім’ї - це витрати на харчування. Багато це чи мало? 3 однієї сторони, в 2016 р. продукти харчування в структурі витрат займали 49,8\%, а в 2013 - аж 50,1\%. Приміром, середньостатистична американська родина витрачає на продукти лише трохи більше $8 \%$ своїх доходів, канадська, австрійська, голландська, німецька й австралійська - від 11 до 13\%. Щодо наших сусідів, то в Угорщині цей показник становить $22,7 \%$, в Польщі - 23,4\%, у Словаччині - 23,9\%, в Румунії - 35,9\% (Derzavna sluzhba statystyky Ukrayiny, 2013-2017)

За даними соціологічної групи «Рейтинг», основними детермінантами приготування i споживання кількості та якості їжі є вік, стать та регіон. На Західній Україні, особливо до свят, збільшуються як придбання продуктів харчування, так і приготування страв. За статистикою українські чоловіки тягнуться до «важких» страв: м'ясні страви, голубці, приготовлені з м'ясом і рисом, холодець, деруни, овочеве рагу, борщ, вареники. У меню молодих чоловіків (до 35 років) увійшли суші, піца, стейки і бургери. У жінок - домінують салати, каші, суші, овочі, риба, фрукти, солодощі. Борщ та «Олів’є» найпопулярніші серед менш забезпечених. А шашлик та відбивна - серед багатшого населення. Міські жителі частіше обирають рибні страви, салати, печеню, суші, торти, піцу. Мешканці сіл надають перевагу традиційним - борщу, вареникам, картопляному пюре та холодцю. Зі збільшенням віку та зниженням освітнього рівня респонденти частіше обирають традиційні українські страви - борщ, вареники чи картоплю. Чим молодші респонденти, тим більше надають перевагу салату «Олів'є», шашлику, смаженій або запеченій картоплі. 3 підвищенням освітнього рівня більше обирають салати, шашлик та відбивні (Sociolohichna hrupa «Rejtyng», 2013; Derzavna sluzhba statystyky Ukrayiny, 2013-2018)

У великих містах та столиці свої «закони»: тут життя динамічне і бурхливе. На харчування чи приготування їжі за часту й часу не має. Тому жителі віддають перевагу швидкій готовій їжі, напівфабрикатам, food drive.

На думку М. Вебера, один із соціологічних законів раціоналізації життя, безпосередньо відбився й на ускладненні та диференціації гастрономічної культури. Приміром, розповсюдження публічним простором американського суспільства емансипативних цінностей призвело до все більшої технологізації гастрономії (Nikolenko, 2015). Відтак у технологічно розвиненому соціумі використовують складні та різноманітні технології приготування страв. Ці тенденції спостерігаємо і в нашому суспільстві. 
Глобалізація привнесла свої корективи у меню українця: традиції закупівлі та приготування їжі змінилися. Швидка їжа та «легкі» вуглеводи заполонили полиці і шлунки людей, ранкове coffe late стало традиційним для молоді та людей середнього віку, не зважаючи на дохід (тут спостерігаємо «ефект просочування»). Наслідком цих процесів сьогодні маємо алергію або «алергію» та лактозу та глютен, боготворіння авокадо (і на противагу цьому - появу терміна Overcado), концепції lowcarb diet, які допоможуть тримати голову у спокої, тіло у тонусі, а фігуру у формі?! Тенденція для середнього класу - це «ловакор»: харчування екопродуктами, вирощеними у місцевості проживання споживача та root-to-shoot (визнання ролі овочів у страві).

Для представників вищого класу у ресторанах починають готувати їжу із використання інноваційних технологій: молекулярна кухня, блументаль, мультисенсорна гастрономія (традиція 30-их рр. ХX ст. Т. Марінетті).

Якщо заглибитися у коріння питання, стає зрозумілим: за усіма цими процесами стоять маркетологи. Відтак консьюмеризм, оніоманія, шопоголізм не забарилися як побічні ефекти у нашому суспільстві, адже ринок, ЗМІ та реклама навмисно інтенсифікують неконтрольоване споживацтво, зокрема і продуктів харчування.

У свою чергу, потужними стимуляторами вибору та споживання їжі, постали мода та брендування. Для осіб старшого покоління не останню роль відіграє влада в особі держави, яка виконує роль годувальника. На молодь свій вплив здійснюють навіть не батьки, а блогери, як ціла субкультура і практика потужної інформаційної маніпуляції.

Цікавим є той факт, що у часи кризи та соціальних трансформацій, люди віком від 40 років і старше починають сповідувати концепцію comfort food - їжі з часів дитинства, коли усе було спокійно, надійно та безтурботно.

Під таким кутом зору гастрономічне, як соціальний феномен, активно впливає на процеси формування ідентичності особи.

Перехід сучасних індустріальних суспільств до епохи постмодерну спровокований цілим рядом соціокультурних змін, які стосуються і феномена споживання їжі, зокрема як засобу відтворення та підтримки соціальних відмінностей.

\section{References}

Burlachuk, V. (2010). Trapeza jak predmet sotsiolohichnoho doslidzenna. Sotsiologija: teorija, metody, marketyng, 4, 179-186. [in Ukrainian]. URL: http://nbuv.gov.ua/UJRN/stmm_2010_4_12

Derzavna sluzhba statystyky Ukrayiny. URL: http://www.ukrstat.gov.ua/

Nikolenko, V. (2014). Gender polymorphism in the context of gastronomic culture: a sociological dimension of the problem. Studies of Changing Societies : Comparative and Interdisciplinary Focus, Vol. 2, 3-39. [in Ukrainian]. URL: http://scsjournal.org/index.php?option=com content\& view $=$ section\&layout $=$ blog\&id $=1 \&$ Itemid $=1$.

Nikolenko,V. (2015). The sociological dimension of the problem of gastronomic culture: the panoramic view of the problem. Studies of Changing Societies : Comparative and Interdisciplinary Focus, Vol. 1, 3-48. [in Ukrainian]. URL: http://scsjournal.org/index.php?option $=$ com content\&view $=$ section\&layout $=$ blog\&id $=1$

Panchenko, V. (2010). Ukrajinske natsionalne kharchuvanna: mynule I majbutne. Uroky zdorovja. Dnipropetrovsk, Herda

Sotsiologichna grupa «Rejtyng» (Rating Group Ukraine), 2013. Narodnyj top: ulubleni stravy ukrajintsiv. URL: http://ratinggroup.ua/research/ukraine/narodnyy top lyubimye blyuda_ukraincev.html

\section{Список використаних джерел}

Бурлачук. В. (2010).Трапеза як предмет соціологічного дослідження. Соціологія: теорія, методи, маркетинг, 4, 179-186. URL: http://nbuv.gov.ua/UJRN/stmm_2010_4 12

Державна служба статистики України. URL: http://www.ukrstat.gov.ua/

Панченко, В. (2010). Українське національне харчування: минуле і майбутнє. Уроки здоров'я. Дніпропетровськ, Герда. 
Соціологічна група «Рейтинг» (Rating Group Ukraine), 2013. Народний топ: улюблені страви українців.

http://ratinggroup.ua/research/ukraine/narodnyy top lyubimye blyuda ukraincev.html

Nikolenko, V. (2014). Gender polymorphism in the context of gastronomic culture: a sociological dimension of the problem. Studies of Changing Societies : Comparative and Interdisciplinary Focus, Vol. 2, 339. [in Ukrainian]. URL: http://scsjournal.org/index.php?option=com content\& view $=$ section\&layout $=$ blog\&id $=1 \&$ Itemid $=1$.

Nikolenko,V. (2015). The sociological dimension of the problem of gastronomic culture: the panoramic view of the problem. Studies of Changing Societies : Comparative and Interdisciplinary Focus, Vol. 1, 3-48. [in Ukrainian]. URL: http://scsjournal.org/index.php?option $=$ com content\&view $=$ section\&layout $=$ blog\&id $=1$

\section{Contact information}

Оксана Макух

oksana.y.makukh@1pnu.ua

Анастасія Луцик

nastyalv1998@gmail.com 